\title{
GONADOTROPHIN LEVELS IN FEMALE RATS SUBJECTED TO RESTRICTED FEED INTAKE
}

\author{
B. E. HOWLAND \\ Department of Oral Biology, The University of Manitoba, Winnipeg 3, Canada
}

(Received 7th Fuly 1971)

Cessation of oestrous cycles and ovarian atrophy have been reported in rats subjected to severe feed restriction (Rinaldini, 1949; Piacsek \& Meites, 1967). Assays of 'total gonadotrophin' in pituitary glands of underfed rats have generally shown elevated hormone concentrations (Rinaldini, 1949; Srebnik \& Nelson, 1963). Piacsek \& Meites (1967) used bioassays that were specific for FSH and LH and reported no difference in FSH concentration but reduced LH concentration in pituitary glands of female rats on $50 \%$ of normal feed intake when compared with fully fed controls. In the case of either elevated or reduced levels of pituitary gonadotrophins, reduced blood levels due to failure of pituitary release mechanisms have been postulated (Srebnik \& Nelson, 1963; Piacsek \& Meites, 1967). The present study was designed to determine the effect of restricted feed intake on serum levels of FSH and LH and to reinvestigate the effect of this treatment on pituitary gonadotrophin levels in female rats of two ages.

Female Sprague-Dawley rats from our own colony were placed in individual cages in a temperature $\left(74 \pm 1^{\circ} \mathrm{F}\right)$ and light $(12 \mathrm{hr}$ light/12 hr dark) controlled room. The animals were assigned to one of four age-treatment groups in an experiment of factorial design $(2 \times 2)$. Age levels were designated as either young ( 8 to 9 weeks old, mean weight $194 \mathrm{~g}$ ) or old (19 to 20 weeks old, mean weight $263 \mathrm{~g}$ ). During a 20-day experimental period, rats of each age were maintained on either a high (HF) or low (LF) feed level. The rats in the HF groups were allowed unrestricted consumption of Purina Laboratory Chow. Rats in the LF groups were restricted to $50 \%$ of normal consumption of the same diet. For the first 10 days, the $50 \%$ restriction was based on feed consumption determined within age groups over a pre-experimental period of 3 days. Beginning on Day 11 , the $\mathrm{LF}$ groups received $50 \%$ of the amount consumed/day by $\mathrm{HF}$ groups of the same age during the first 10 days of the experiment. On the morning of Day 20, blood samples were obtained by heart puncture. The animals were then killed and right ovaries and anterior pituitary glands were removed and weighed. Pituitary glands and sera were stored frozen for later assay of FSH and LH.

The concentration of LH in pituitary homogenates and sera was determined by the $0-0$ radioimmunoassay described by Niswender, Midgley, Monroe \& Reichert (1968). The standard used was NIAMD rat-LH-RP-1 and the results were expressed in terms of this preparation. A similar double antibody radioimmunoassay, distributed by the National Institute of Arthritis and Metabolic 
Diseases, NIH, was used to measure FSH concentrations in the same samples. Data for FSH were expressed in terms of NIAMD rat-FSH-RP-1.

The data were analysed by analysis of variance with sums of squares adjusted for unequal subclass numbers by the use of the harmonic means of $N$ (Snedecor, 1956).

Rats in LF groups gained less weight and had ovaries and pituitary glands that weighed less than rats in HF groups $(P<0.01$ for each characteristic, Table 1). In the case of ovarian weight, the feed level effect was greater in the young rats than in the old rats, as indicated by a feed level $\times$ age interaction

TABLE 1

EFFECT OF FEED LEVEL AND AGE ON BODY, OVARY AND ANTERIOR PITUITARY GLAND WEIGHTS

\begin{tabular}{l|c|c|c|c}
\hline & \multicolumn{2}{|c|}{ Young rats } & \multicolumn{2}{c}{ Old rats } \\
\cline { 2 - 5 } & $\begin{array}{c}\text { High } \\
\text { feed level }\end{array}$ & $\begin{array}{c}\text { Low } \\
\text { feed level }\end{array}$ & $\begin{array}{c}\text { High } \\
\text { feed level }\end{array}$ & $\begin{array}{c}\text { Low } \\
\text { feed level }\end{array}$ \\
\hline No. of rats & 5 & 8 & 5 & 6 \\
Body wt gain $(\mathrm{g})^{\mathrm{a}, \mathrm{b}}$ & $36 \pm 6^{\mathrm{c}}$ & $-32 \pm 4$ & $17 \pm 4$ & $-58 \pm 6$ \\
Right ovary wt $(\mathrm{mg})^{\mathrm{a}, \mathrm{d}}$ & $38 \pm 3$ & $22 \pm 2$ & $34 \pm 2$ & $30 \pm 2$ \\
Pituitary wt $(\mathrm{mg})^{\mathrm{a}, \mathrm{b}}$ & $10 \cdot 9 \pm 0 \cdot 7$ & $7 \cdot 2 \pm 0 \cdot 5$ & $13 \cdot 2 \pm 0 \cdot 4$ & $10 \cdot 9 \pm 0 \cdot 8$ \\
\hline
\end{tabular}

a Feed level, $P<0.01$.

Age, $P<0.01$.

c Mean + S.E.

d Feed level $x$ age, $P<0.05$.

$(P<0.05)$. Over both feed levels, old rats gained less weight $(P<0.01)$ and had heavier pituitary glands $(P<0 \cdot 01)$ than did the young rats.

Pituitary and serum LH and Fst data are summarized in Table 2. Pituitary LH concentration was not affected by either feed level or age. However, the larger gland size in old rats resulted in a greater $(P<0.05)$ total gland content of $\mathrm{LH}$ for old animals compared to young animals. The observation that the low feed level did not alter pituitary LH concentration is in agreement with the results obtained in a previous study in this laboratory (Howland \& Ibrahim, 1971), but disagrees with the reduction in pituitary LH concentration in the underfed rat reported by Piacsek \& Meites (1967). In the latter study, the experimental feeding period was longer which may explain the drop in LH that was observed, but further studies will be required to clarify this point.

Pituitary FSH concentration was higher $(P<0.01)$ in LF groups than in HF groups. However, since the low feed level resulted in a reduction in pituitary weight, the gland content of FSH was not affected by feed level. Although Piacsek \& Meites (1967) were unable to detect any change in FSH concentration in pituitary glands due to underfeeding, increased 'total gonadotrophic' potency of pituitary tissue from underfed rats has been reported (Srebnik \& Nelson, 1963).

The mean serum LH concentration was reduced in the LF groups to about half of that observed in the HF groups $(P<0 \cdot 01)$, but no treatment differences in serum FSH concentration were detected. A similar reduction in blood levels of 
LH in rats subjected to $50 \%$ feed restriction was observed in a previous study (Howland \& Ibrahim, 1971). Since LH levels in the rat are low except during the afternoon and evening on the day of pro-oestrus (Monroe, Rebar, Gay \& Midgley, 1969), the values reported for this study were presumed to be basal levels.

The results of this study suggest that the reduced ovarian weight and function in underfed rats is due in part to a deficiency in basal LH secretion. The fact that the pituitary concentration of $\mathrm{LH}$ was not reduced by restricted feeding indicates that synthesis and release of hormone were equally impaired and is consistent with the hypothesis that undernutrition acts on the pituitary gland by inhibiting hypothalamic production of LH-releasing factor (Piacsek \& Meites, 1967). The elevated pituitary concentration of FSH in the underfed rats suggests that treatment altered the balance between hormone synthesis and release. The

TABLE 2

EFFEGT OF FEED LEVEL AND AGE ON PITUITARY AND SERUM GONADOTROPHIN LEVELS

\begin{tabular}{l|c|c|c|c}
\hline & \multicolumn{2}{|c|}{ roung rats } & \multicolumn{2}{c}{ Old rats } \\
\cline { 2 - 5 } & $\begin{array}{c}\text { High } \\
\text { feed level }\end{array}$ & $\begin{array}{c}\text { Low } \\
\text { feed level }\end{array}$ & $\begin{array}{c}\text { High } \\
\text { feed level }\end{array}$ & $\begin{array}{c}\text { Low } \\
\text { feed level }\end{array}$ \\
\hline Pituitary LH conc. $(\mu \mathrm{g} / \mathrm{mg})$ & $14 \cdot 3 \pm 2 \cdot 9^{\mathrm{a}}$ & $16 \cdot 3 \pm 2 \cdot 4$ & $14 \cdot 0 \pm 1 \cdot 7$ & $18 \cdot 5 \pm 4 \cdot 3$ \\
LH content $(\mu \mathrm{g} / \mathrm{gland})^{\mathbf{b}}$ & $148 \pm 22$ & $114 \pm 16$ & $185 \pm 24$ & $188 \pm 38$ \\
Pituitary FSH conc. $(\mu \mathrm{g} / \mathrm{mg})^{\mathrm{c}}$ & $1 \cdot 86 \pm 0 \cdot 23$ & $2 \cdot 56 \pm 0 \cdot 13$ & $1 \cdot 45 \pm 0 \cdot 16$ & $2 \cdot 52 \pm 0 \cdot 48$ \\
FSH content $(\mu \mathrm{g} / \mathrm{gland})$ & $19 \cdot 7 \pm 1 \cdot 1$ & $18 \cdot 1 \pm 0 \cdot 9$ & $19 \cdot 2 \pm 2 \cdot 3$ & $25 \cdot 9 \pm 4 \cdot 1$ \\
Serum LH conc. (ng/ml) & $27 \pm 6$ & $12 \pm 1$ & $34 \pm 8$ & $15 \pm 1$ \\
Serum FSH conc. (ng/ml) & $215 \pm 27$ & $201 \pm 14$ & $217 \pm 21$ & $254 \pm 9$ \\
& a Mean \pm S.E. & & \\
\hline & ' Age $P<0 \cdot 05$. & \\
& c Feed level $P<0 \cdot 01$.
\end{tabular}

experiments reported by Piacsek \& Meites (1967) suggested that blood levels of FSH in underfed rats were low and that underfeeding impaired FSH release. In male rats, starvation has been shown to reduce the hypothalamic content of FSH-releasing factor, but pituitary FSH concentration was also reduced (NegroVilar, Dickerman \& Meites, 1971). Assuming that undernutrition can reduce the hypothalamic production of FsH-releasing factor, one might predict from the elevated FSH levels in pituitary glands of the rats on restricted feed intake, that serum levels would be low as a result of impaired hormone release. The assays of serum FSH, however, did not bear this out. A possible explanation for the elevated pituitary FsH levels observed in the underfed rats is that the hormone accumulated as a result of absence of the periovulatory release, while hormone synthesis and basal secretion remained unchanged.

The author is grateful to Dr G. D. Niswender for providing the antiserum and to Dr L. E. Reichert, Jr, for providing the ovine LH for labelling, both of which were used in the LH radioimmunoassay and to the National Institute of Arthritis and Metabolic Diseases, Rat Pituitary Hormone Program for the rat 
FSH radioimmunoassay reagents and the rat LH pituitary standard. This work was supported by M.R.C. Canada grant MA-4454 and a grant from the National Research Council of Canada (A-6248).

\section{REFERENCES}

Howland, B. E. \& Ibrahm, E. A. (1971) Effect of level of feeding on pituitary and plasma LH concentration in the female rat. Proc. 21 st Ann. Meet. Can. Soc. Animal Prod., Lethbridge (in press).

Monroe, S. E., Rebar, R. W., Gay, V. L. \& Midgley, A. R., JR (1969) Radioimmunoassay determination of luteinizing hormone during the estrous cycle of the rat. Endocrinology, 85, 720.

Negro-Vilar, A., Dickerman, E. \& MeItes, J. (1971) Effects of starvation on hypothalamic FshRF and pituitary FSH in male rats. Endocrinology, 88, 1246.

Niswender, G. D., Mmgley, A. R., Jr, Monroe, S. E. \& Reicherr, L. E., JR (1968) Radioimmunoassay for rat luteinizing hormone with anti-ovine $\mathrm{LH}_{\mathrm{H}}$ serum and ovine $\mathrm{LH}^{-{ }^{131}}{ }^{1} \mathrm{I}$. Proc. Soc. exp. Biol. Med. 128, 807.

Piacsek, B. E. \& Meites, J. (1967) Reinitiation of gonadotropin release in underfed rats by constant light or epinephrine. Endocrinology, 81, 535.

Rinaldini, L. M. (1949) Effect of chronic inanition on the gonadotrophic content of the pituitary gland. 7. Endocr. 6, 54.

SNedecor, G. W. (1956) Statistical methods, 5th edn. Iowa State College Press, Ames, Iowa.

SRebnIK, H. H. \& Nelson, M. M. (1963) The influence of diet on the gonadotrophins of the anterior pituitary gland. Proc. 6th Int. Congr. Nutr. p. 375. Eds. C. F. Mills and R. Passmore. Livingstone, Edinburgh. 